\title{
Constitutional Recognition: reflecting on the prospect and direction in the 46th Parliament
}

\author{
Ashley Cleavin \\ University of Technology Sydney, Faculty of Arts and Social Sciences, PO Box 123, Ultimo \\ NSW 2007, Australia.natane.cleavin@student.uts.edu.au
}

In an election campaign that spent much time around esoteric ideas like dividend imputation credits and electric vehicle targets, it is strange that little time was spent discussing Labor's proposal to enshrine a Voice to Parliament for First Nations people in the constitution, via referendum. Unlike nations such as New Zealand or Norway, Australia lacks a specified mechanism for First Peoples' political representation. As with our decades of inaction on constitutional recognition of Australia's Indigenous peoples, this can also be seen manifesting in our inability to improve educational, health, and justice outcomes for Indigenous Australia. Individuals like newly appointed Minister for Indigenous Affairs, Ken Wyatt, and Member for Barton, Linda Burney, can and do break through this glass ceiling. But such examples serve as outliers rather than the norm, as Indigenous Land Rights leader Galarrwuy Yunipingu noted, 'I have had a place at the table of the best and the brightest in the Australian nation - and at times success has seemed so close, yet it always slips away' (Yunipingu 2008, para. 20). The Uluru Statement from the Heart sought to show a path forward from the 'torment of our powerlessness' and for 'reforms to empower our people and take a rightful place in our own country'.

Rather than recognition for recognition's sake, the proposed First Nation's voice in Parliament seeks to act as Noel Pearson suggests in 'ensuring that Indigenous people get a fair say in laws and policies made about us without compromising the supremacy of parliament' (Pearson 2014, p. 66). At the time of its release, the then Turnbull Government shelved the proposal 'as a third chamber of Parliament' (PM 2017, p.5) without 'any realistic prospect of being supported by a majority of Australians' (PM 2017, p.7). Many argue that a Voice that informs Parliament when it makes new laws does not constitute a third chamber, as law professor, Anne Twomey notes, 'other bodies that inform parliament, like the Productivity Commission, aren't considered third chambers as they have no power to initiate, pass or reject bills' (Twomey 2019). Such is the Overton window in Australia, that instead of looking at the 
various Sami parliaments that exist in Scandinavia, academics instead argue the case that the proposal doesn't go as far as is claimed.

Perhaps those who 'don't want separatism' (Pearson 2014, p.66) but are okay with 'inclusion on a fair basis' (Pearson 2014, p.66) can look to New Zealand, where Maori represent their electorates in the same chamber as the general roll. While the Government initially dismissed the Uluru proposal, its allocation of money to further develop the plan shows hope for a future change in attitudes and appetite for such a move to gain favour with Australians.

\section{References}

Pearson, N. 2014, 'A Rightful Place', Quarterly Essay, September 2014, viewed 5 June 2019, <https://www.quarterlyessay.com.au/essay/2014/09/a-rightful-place>.

Prime Minister of Australia 2017, Media Release, Canberra, viewed 5 My 2019, <https://www.pm.gov.au/media/response-referendum-council\%E2\%80\%99s-reportconstitutional-recognition>.

Twomey, A. 2019, 'Why an Indigenous voice would not be a 'third chamber' or parliament', blog, The University of Sydney, Sydney, 28 May, viewed 5 June 2019,

$<$ https://sydney.edu.au/news-opinion/news/2019/05/28/why-an-indigenous-voice-would-notbe-a-third-chamber-of-parliament.html> .

Yunipingu, G. 2008, 'Tradition, truth \& tomorrow', The Monthly, December 2008, viewed 5 June 2019, <https://www.themonthly.com.au/issue/2008/december/1268179150/galarrwuyyunupingu/tradition-truth-tomorrow $>$. 